\title{
Political ecology and conservation policies: some theoretical genealogies
}

\author{
Ismael Vaccaro $^{1}$ \\ Oriol Beltran \\ Pierre Alexandre Paquet \\ McGill University, Canada \\ Universitat de Barcelona, Spain
}

\section{Introduction}

Over the last twenty years, conservation has become a central analytical focus in the social sciences. This review article brings together contributions to the understanding of the political ecoloqy of conservation in an attempt to unveil the conceptual genealogies that connect the work of anthropologists, geographers, political scientists, and sociologists. We also set out the historical chronologies of the political ecology approach to conservation.

The interest in conservation started as a trickle of studies on specific protected areas and their human communities (Carruthers 1995; Duffy 1997; Neumann 1992; Ranger 1999; Stevens 1997) and quickly became a stream that included study cases of all sorts including numerous monographs (Brockington 2002; Haenn 2005; Heatherington 2010; Igoe 2003; Theodossopoulos 2003; Wallev 2004; West 2006) and articles (Berkes 2008; Chapin 2004; Lowe 2004; Moore 1998a; Wilshusen 2010) amongst many others. Case studies were soon followed by theoretical work that attempted to create a general framework for understanding conservation (Borgerhoff-Mulder and Copolillo 2004; Brockington and Duffy 2011; Brockington, Duffy, and Igoe 2008; Milton 1996; Orlove and Brush 1996; West 2005; West, Igoe, and Brockington 2006; Zimmerer 2006). Political ecology textbooks have included chapters on conservation (Neumann 2004; Robbins 2005).

A wave of articles connected conservation to specific issues such as climate change (Berkes and Jolly 2002), forced displacement (Agrawal and Redford 2009), or tourism (Münster and Münster 2012). The bibliographic field was consolidated by the publication of several edited collections (Anderson and Berglund 2003; Brosius, Tsing, and Zerner 2005; Stevens 1997; Zimmerer 2006), and several special journal issues. ${ }^{2}$ The American Association of Anthropology even has a task force on conservation, called the Community and Conservation Working Group (Peterson, Russell, West, and Brosius 2010).

\section{Political ecology, conservation, and history: chronologies}

Political ecology defines the environment as an arena where different social actors with asymmetrical political power are competing for access to and control of natural resources (Bryant and Bailey 1997). The act of declaring and implementing a conservation policy is a paradigmatic example of this competition for environmental control. Protected areas, by definition, establish jurisdictions and borders that define exclusionary rights. They are implemented by different social and institutional actors (often powerful), suffered by other social groups (often not so powerful), and enjoyed by yet another set of players (tourists and scientists). These discrete actors, therefore, remain engaged in an assemblage of contradictory social relationships. These different social actors define nature, legitimacy, rights, or use in very different, and culturally dependent, ways. It is not surprising, then, that political ecology, from its very beginnings, devoted analytical attention to the socio-ecological context of conservation policies (Neumann 1992). Political ecology emphasized the connections between ecology and social context by matching ecological and social chronologies, contributing to the understanding of their interactions and the social production of landscapes (Blaikie 1985; Fairhead and Leach 1996; Vayda and Walters 1999).

\footnotetext{
${ }^{1}$ Dr. Ismael Vaccaro, Associate Professor, Dept. of Anthropology (and School of Environment), McGill University, 838 Stephen Leacock Building, 855 Sherbrooke Street W., Montreal, Quebec, H3A 2T7, Canada. Email: ismael.vaccaro "at" mcgill.ca. Dr. Oriol Beltran, Professor of Social Anthropology, Universitat de Barcelona, Spain. Email: Obeltran "at" ub.edu. Pierre Alexandre Paquet, PhD student, Dept. of Anthropology, McGill University, Canada. Email: pierrealexandre.paquet "at" mail.mcgill.ca. Thankyou to three reviewers and the editors.

${ }^{2}$ Annual Review of Anthropology 2006; Conservation and Society 2007; Antipode 2010; Development and Change 2012; Journal of Peasant Studies 2012.
} 
Although conservation is a vast field, with many different types of policies, in these pages we mainly focus on territorially based conservation policies: the creation of protected areas. We are, however, interested in disentangled the conceptual genealogies used by political ecology in particular, and social sciences in general, to talk about and to analyze such policies. Admittedly, not all protected areas are the same. The goal of this article is not talk about the differences between national parks, natural parks, or reserved areas for instance, nor to discuss the impact of UNESCO or IUCN on the development of conservation areas. Descriptive analysis and detailed critical inventories can be found elsewhere (Europarc 2008; Santamarina 2009; Lausche 2012; UNESCO 2012).

Grosso modo the literature has created an historical framework of analysis that describes the evolution of the territorially based 'conservationist industry' in three main phases (Wilshusen et al. 2002);

a) fortress conservation (Brockington 2002; Neumann 1998)

b) different forms of co-management conservation (Brechin et al. 2003; Brosius, Tsing, and Zerner 2005; Gibson and Marks 1995; Peters 1998)

c) neoliberal conservation (Brockington and Duffy 2011; Igoe and Brockington 2007).

Neoliberal conservation appears to have created a backlash against previous participatory models and provoked a return to an austere - and marked-dominated - 'quasi-fortress' model, with some important changes, including a concentration of capital, of science and of political clout in private hands. This authoritarian backlash manifests as privately owned 'fortress' conservation areas or in the interaction between private exploitation ventures and the public conservationist effort (Fortwangler 2007; Langholz 2003; Brosius and Russell 2003; Peterson et al. 2010).

Modern conservation, in the form of territorial exclusionary policies, appears at the end of the nineteenth century as a key cultural element of the relationship that dominantly urban Western societies develop with nature. At the heels of the political and economic globalization that came with the Industrial Revolution, conservation policies quickly became ubiquitous and a source of local tensions around the globe (Tsing 2005). They also became a tool for territorial homogenization and cultural universalization (Sullivan 2010) as they stepped over alternative pre-modern - non-state dominated - forms of territorial management such as the commons, for instance (Ostrom et al. 2002). Conservation is also culture: exclusionary territorial public policies are a modern way of socially constructing and politically controlling nature (Bromley 1991) and landscape (Hirsch and O`Hanlon 1995); of turning place into space (Feld and Basso 1996).

The three phases of modern conservation, although they emerged in different historical moments, coexist in time in many different locales, or they succeed each other depending on the vagaries of the protected area management in charge at the time: led by government officials, NGO priorities, or notions of environmental stewardship prevailing at all stakeholder levels, including the local (Zanotti 2011). The three categories in this classification scheme are, of course, ideal types. They are, in themselves, categories that encompass high levels of historical, geographical, and institutional variability. The historiography of conservation is context dependent, as are the political forms and ideologies that have dominated public policy and the production of science in general (Adams and Hutton 2007).

\section{Fortress conservation}

This is the first stage of public conservation, established as originating in the US following the Yellowstone National Park model, founded in 1872 (Spence 1996). Fortress conservation is characterized by an exclusionary approach: it has often resulted in evictions of local inhabitants. It also focuses part of its managerial efforts on protecting and defending its borders from outsiders. More often than not, the managerial body does not share jurisdiction with locals or local institutions (Brockington 2002; Peluso 1992, 1993). This approach is by no means limited to the early parks of the late nineteenth century. Fortress conservation is still implemented, and its adequacy is often questioned (Wilshusen et al. 2002). This model is often used to present conservation discourses akin to modernity's main narratives, characterized by the implementation of state bureaucratic governmentality (Lowe 2006), dominated by experts (Saberwal et al. 2001), state-making (Vaccaro 2005), and ultimately linked to commoditization (Castree 2003). Protected nature not only becomes a commodity worth paying to see and experience; it is printed on posters, it is traded as a strategic good in international agreements, and an industry has emerged around its exploitation. The inclusion of conservation into the public realm is also closely related to the development of the idea of 'collective public good' as a fundamental legitimating argument for state intervention (Foucault 2007), and the typification of acceptable behavior (Duffy 2010).

Most of the time the newly created parks were focused on peripheral, often mountainous environments that in many cases are also populated by marginal populations, as seen by the respective national imaginaries (Santamarina 2008). This initial phase of territorially based conservation is articulated 
around very specific ideas of what nature is from a cultural, but also from a political perspective. The inefficiencies of the fortress model have pushed the conservationist movement (and its public and private bureaucracy) to rethink the paradigm, due to continued local resistance and accusations of environmental injustice (Adams and Hutton 2007; Robbins 2005). These policies are, as we will see, articulating a new form of colonialist reconceptualization of nature, landscape, and society.

\section{Co-managed conservation}

At some point many contesting voices started to claim what became quite obvious: imposed conservation resulted in extensive environmental iniustices associated with the violation of traditional local rights to land and resources. Imposition often led to local opposition and attacks against outsider governance, and even against the natural assets themselves (Stevens 1997; West and Brechin 1991). This opposition appears to be part of wider social movements, especially in the Third World (Guha 1999). There seems to be a convergence between;

a) postcolonial independence struggles that spurred demands for more political and economic recognition, inclusion, and empowerment of non-Western actors, giving birth to participatory approaches to development (Argiyrou 2005; Escobar 1995)

b) the recognition of the role local communities have had in the management (or even creation) of valuable environments (Cinner and Aswani 2007; Posey and Balick 2006; Redford and Mansour 1996; Toledo et al. 2003)

c) the introduction of the concept of sustainable development, which interlinks social and ecological systems over time (WCED 1987).

d) the recognition that policies had different impacts of different intensity on diverse communities and on different types of social actors inside these communities (Bryant and Bailey 1997; Schlosberg 2007).

The acknowledgement of this internal heterogeneity of the communities affected by conservation and development projects has led to the analysis of the consequences for different groups of individuals, depending on their identities or positionality. Subaltern groups, because of their productive choices, gender, or social standing, are also part of local communities, have strong local relationships with the natural environment, and often endure the worst consequences stemming from the sudden and radical changes brought about by conservation policies (Agrawal 1996; Carney and Watts 1991; Rocheleau et al. 1996).

Sustainable development also bound together concerns for environmental conservation with the riaht to development (Sachs 1999). In the 1970s, the political claims of the newly independent countries of the Third World and the idea of sustainable development were introduced into the conservationist agenda. Conservation proper became enshrined in conservation-as-development projects (West 2006). Even institutions like the World Bank worked on the 'greening' of their policies (Goldman 2006) and adopted participatory approaches during this period. There was, then, a strongly felt need to redefine conservation policies and, especially, conservation's relationships with the local populations with which they were in direct contact. Conservationist NGOs such International Union for the Conservation of Nature (IUCN) and the World Wildlife Fund for Nature (WWF) and many others, started to redefine concepts such as nature, use, or jurisdiction in order to consider nature and culture in their work (Santamarina 2008). The resulting international agreements were designed to integrate pre-modern forms of environmental management and local communities into conservationist institutional networks. This interaction resulted in a generalized change in the discourse and practice of conservationist ideology in regard to the acceptance of human use and habitation inside protected areas. In terms of governance, this meant the devolution of iurisdiction from central authorities to local partners, partially through co-management, or fully as community-based conservation (Brosius et al. 2005; Igoe and Croucher 2007; Western and Wright 1994).

This process occurred simultaneously with a wave of successful indigenous land claims in some places including Australia (Bergin 1993; Lewis 1989) and South Africa (Reid 2001; Steenkamp 1998). In Australia, following the Native Title Act (1993) and the subsequent wave of successful land claims, the federal government instituted the Indigenous Protected Areas program that allowed local communities with land titles to access additional public resources in return for conservation efforts on their land (Langton, Rhea and Palmer 2005). At the same time UNESCO was promoting the Biosphere Park program, which accepted varving degrees of human use in the different zones of their protected areas (Batisse 1982). Different conservationist organizations adopted some elements of this co-management framework and developed their own programs. Community Based Natural Resource Management (CBNRM) programs sustained by WWF and other Western nongovernmental agencies and governments proliferated as a way to connect local 
development with conservation (Blaikie 2006; Fabricius et al. 2004). During the late 1980s, 1990s and early 2000s the WWF gave support to Integrated Conservation and Development Projects (ICDPs) (Chapin 2004).

\section{Neoliberal conservation}

It was almost predictable that at some point researchers, managers, and stakeholders alike would start thinking in terms of the economic sustainability and long-term viability of each conservation policy. Conservation policies require resources to function and, with a few exceptions, parks, parklands and protected areas usually do not generate enough income to sustain their protection or continued habitation (McCarthy and Prudham 2004). These areas need continuous inputs from governments or external institutions to endure over time (Corson 2010). Tourism, and subsidies from governments, NGOs, or companies interested in gaining green respectability, have become a fundamental part of the managerial plans of protected areas (Igoe 2010; Sullivan 2012). These financial and legitimacy transfers have often been negotiated with complete disregard to local and indigenous peoples (Chapin 2004; West et al. 2006; MacDonald 2010). In the current installment of conservation during global economic recession, protected nature has become a commodity to be sold by governments, multinational organizations, or companies on international markets; as political or economic leverage (Igoe and Brockington 2007; Hardin 2011). This process amounts to a deregulation of conservation, where privatization and environmental alienation take on an increasingly larger role (Fortwangler 2007; Robertson 2006).

In this framework the United Nations-Reducing Emissions from Deforestation and Forest Degradation in Developing Countries program (REDD) plays a significant role because of its growing dimensions, but also because of the rationality that informs it. The program is based on trading sound environmental behavior from the South in return from funding from the North (Harvey et al. 2009). Despite not dealing with stable and established conservation areas, the program has territorial and managerial global consequences of immense proportions.

Neoliberal conservation, framed by global economic crisis from 2008, is occurring hand in hand with a general neoliberalisation of the societies that traditionally funded conservation across the world. Privatization is happening in some places (Reid 2011; Heynen et al. 2007; Igoe and Brockington 2007), while in others, plain dismantling of the conservationist public administration and its policies is occurring, resulting in an effective decapitalization of conservation. The consequences of this have not been comprehensibly studied (Cooper 2010; Pellizzoni 2011).

The increase in importance and popularity of the political ecology of conservation has gone hand in hand with a parallel increase of the social significance of conservation itself. This article attempts to unveil some of the theoretical genealogies that conflate in the social analysis of conservation. Analyzing conservation as an ideological and political phenomenon requires an analysis of the changes and implications that conservation has undergone in three distinct but closely related fields: territorial governance (politics), market integration (economy), and taste (cultural values). This, in other words, is an inquiry into the impacts of the "great transformation", the consolidation of modernity via the unfolding of modern states and the capitalist market on the field of environmental conservation (Polanyi 1944).

In the chronology above, conservation became a quintessential product of late modernity due to the structural framework of its implementation, both from the point of view of political power interactions and economic rationalization, or market integration, and the cultural changes required for its mainstream consolidation (Appadurai 1996; Baudrillard 1998; Harvey 2001). The creation of a protected area is as much a social process with political and economic consequences as it is an ecological project in which stakeholders' managerial, and consequently, cultural preferences and knowledge, play a fundamental role (Forsyth 2002, Cooper 2000; Saberwal and Rangajaran 2003; Vaccaro and Beltran 2009). Interestingly enough, this chronology also illuminates the presences and absences that dominate critical studies of conservation: the chronology itself, with its three phases, is defined by the managerial and ideological structure that controls the policy, and focuses mostly on the discourses that articulate it as a more or less permanent institutional performance of power. The interaction of these technologies of power with the environment itself and the ecological mobility of the landscapes that they protect is an element that, surprisingly, often remains outside the scope of analysis (Balée 2006; Vayda and Walters 1999). This trend may have had an impact on the difficult interactions between political ecologists and a conservationist world dominated by ecologists and conservation biologists.

Social sciences first approached conservation by focusing on its social consequences, especially the political dimensions and through the effects on livelihoods and subsistence of affected populations. In the fortress conservation model, the exclusion of territory from human use was meant to protect nature from 
anthropogenic destruction. External institutions of urban origin decided the extent of enclosure (Cronon 1996). This type of conservation allegedly protected that particular habitat from external abuse but it also left local rural populations without access to historically held resources fundamental for their survival, or at times, it involved the forced relocation of local populations (Blaikie 1985; Nietschmann 1973). This political inequality inherent to conservation policies resulted in research on the political economy of conservation and on analysis of the differentials of power between the local and external stakeholders in such processes. On the ground, it yielded historical analysis of transformations of tenure regimes and demographic settlement patterns, and also the understanding that identity markers such as class, gender, or ethnic belonging do have an impact on those same regimes. Conservation studies combined the analysis of modern policies and their consequences for local politics and economics with three classic interests of environmental social sciences;

a) the human ecology of indigenous communities (Orlove 1980)

b) their traditional ecological knowledge (Dove 2006; Hunn 2008)

c) and the impacts on local 'isolated' communities of political or regional integration into larger units (Ensminger 1992; Peters 1994; Scott 1998).

Typical questions were: what were the productive practices of the populations affected by parks before their implementation? Could these economic practices and these ways of life be sustained by the resources left to these communities after the implementation of conservation enclosure? Who are the competing actors, what are their histories, and how do they interact in the process of inherent transformation behind the implementation of protected areas?

The analysis of the historical development of conservation also points to yet another key conservationist dilemma: one that goes beyond management and delves into a fundamental ideological opposition. Is the enjoyment of conservation spaces a basic right of all citizens and consequently, should access to protected areas be granted democratically? Or should access be limited, for reasons of environmental integrity, to a few privileged visitors? On one side we encounter elitist visions of conservation, associated with exclusion and privilege where local access to resources and visitors' flows of people are limited (Holmes 2011, 2012). In these circumstances high-end tourist packages make economic development (the commoditization of nature) and conservation compatible with a low level of impact. Luxurious ecotourism seems to actualize older models of nature enjoyment: aristocratic hunting reserves, or wildlife expeditions (Beltran 2012). In fact, the first protected areas promoted by the states, inside the national borders or in the colonial territories, were equally directed to privileged sectors of the population. On the other side we encounter a more democratic (socializing) vision of conservation — where the idea of a protected area (national in its origin, but soon regional, for the common good) is connected with the idea of rights of access. Nature is, in this perspective, more a civil right than exclusive merchandise. Under this approach the role of public institutions in conservation initiatives as well the very notion of nature as national patrimony would be sustained by the explicit goal of making nature accessible to large segments of the population (Floyd 2001).

On occasion public use becomes a priority ahead of conservation itself: the only effective intervention by the authorities is the management of the visitors themselves (services, access infrastructure, and to limit their impact) with the approach being closer to tourism promotion than strict environmental protection. In urban parks in or near metropolitan areas, the services provided by protected spaces are considered more important than the actual integrity or authenticity of 'natural' characteristics. Near cities, green areas are scarcer than agricultural landscapes (the traditional enemy of 'pristine' environments) and these may be included in the conservationist effort (Lai 2013). Conservation areas have tended to privilege environmental integrity or biodiversity preservation as the reason for or the goal of protection. Urban protected areas are more directed at ensuring air quality or leisure areas for the inhabitants of the city (Rademacher and Sivaramakrishnan 2013).

\section{Conceptual genealogies}

This third section focuses on the intellectual genealogies of some of the most relevant concepts needed to discuss the architecture of conservation. To achieve this goal we subdivide this section into three blocks: state, market, and culture. We understand the emergence of conservation as a social transformation, as a change that occurred amidst of a more general process of complete social metamorphosis: the emergence of modernity (Polanyi 1944). The implicit analytical structure deployed by the three fields defined in the second section, mirrors Gramsci's analysis of socioeconomic transitions (2011). In the modern mode of production close attention needs to be paid to the consolidation of the capitalist state (economy and politics), and the fundamental cultural shifts that accompany every major social transformation (culture). 
The division of the intellectual genealogies of conservation in three fields is, of course, a heuristic device. The development of the state, and concepts such as governmentality and territoriality, cannot be understood without the concurrent unfolding of the capitalistic market and its mass production and consumption networks, and the cultural shifts that have facilitated their hegemonic prevalence.

\section{The state: or, the politics of conservation}

It is clear, in any case, that the creation of a protected area results in a redistribution and a renegotiation of the political economy in a locale (Gibson 1999). The rationality and structures that govern access to and control of natural resources are modified by the intervention of an external political body (Anderson and Berglund 2003; Neumann 1998). Accordingly, proponents of new institutionalism with its emphasis on land tenure (Bromley 1992; Hann 2003) and collective action (Ostrom 1990; Ostrom et al. 2002) have identified the behavioral and economic impacts of extracting the land from local jurisdictions to transfer it to an impersonal and external managerial entity.

The finding is that conservation is closely tied to state integration and state-making projects (Craib 2004; Vandergeest and Peluso 1995). Through conservation, the state extends its administrative grasp over of its territory. The nation is territorialized by homogenizing the management of its natural spaces (Lefebvre 1974; Winichakul 1997). As modern nation-states try to assert control in this way, cultural landscapes and natural phenomena are integrated into emerging or changing national identities by the different nationalist romanticisms that create an ideological and literary base for the integration of the environmental and cultural past of the nation (Anderson 1983; Storev 2012). Environmentalism becomes part of the armamentarium of the nation, part of its statemaking ideology (Cederlof and Sivaramakrishnan 2006). What sustains, what provides legitimacy to the state's claim to a monopoly on the conservation of nature, is the idea of collective heritage and best available science. Collective heritage is the cultural elements or landscape features defined as intergenerational patrimony in need of 'public' protection (Roigé and Frigolé 2011). The creation of heritage, in turn, constructs the national and local communities alike through symbolic practice (Augé 1994; Davallon 2006). Patrimonialization (the attribution of heritage status) is a process that has cultural, symbolic, institutional, economic, and administrative manifestations.

Weber (2011 [19041) and Gellner (1983) describe the emergence of the modern nation-state as the consolidation of an impersonal bureaucratic machine that claims, on behalf of the citizenry, a monopoly over key collective jurisdictions (law, violence, education, amongst others). The fact that sovereignty has moved from a monarch to a national collectivity (the citizenry) in most cases, is what provides legitimacy to this claim. This monopolistic claim by the emerging modern nation state to the control of territory and natural resources translates into the imposition of a specific form of governmentality (Dean 1999; Foucault 2007, 2008) based on national territoriality (Delaney 2005; Hannah 2000; Sack 1986). A form of government focused on conservation and natural resource management emerges (Agrawal 2005; Büsher and Dressler 2007; Sivaramakrishnan 1999). Natural resource management is assessed by specialists, by scientists who, on behalf of the public institutions, generate knowledge and decide from the perspective of abstract managerial or political needs (Fairhead and Leach 1996; Escobar 1998; Guha 2000). These specialists interact with local people and from this interaction new regimes of nature emerge (Moore 1998b; Mathews 2011). The state, imbricated with the market, develops new forms and practices of governance (Carrier and West 2009).

Claims of heritage and global importance were also used in the past by the colonial administrations, to justify their territorial interventions in the name of ecological preservation and management (Griffiths and Robin 1997; Grove 1995). Imperial expansion went hand in hand with a development of managerial rationalities in tropical environments (Mackenzie 1988; Pels 1997; Rangajaran 1996). Nature became a cultural signifier that went beyond national boundaries.

\section{The market: or, the economics of conservation}

Not surprisingly, this process of revalorization of nature into a collective asset and as part of public heritage quickly attracted the attention of economic interests. Economic interests, in turn, redefine heritage as any valuable environment capable of generating revenue via tourism. Natural heritage becomes vet another commodity within a large (global) market (Hayden 2003; Woods 2007). The commoditization of natural heritage and the valorization of nature by state-directed conservation practices are in competition with other (local) uses, such as ranching, agriculture, mining, tourism, or forestry. All are at a landscape scale, at which conservation occurs. Protection, then, is implemented in opposition or in articulation with some of these possible uses of the land.

Environmental economics has also helped reconceptualise nature as giving potential ecological services, gains, and costs. This strain of conservationist thought has put a price on nature, attempting to prove the cost of its degradation (Kosoy and Corbera 2010) or justify its preservation. At a certain level the environment has been rebranded, becoming a 'pool' of natural resources (Sullivan 2009). In a market 
situation, these resources and their value can be traded against other things. Nowhere this logic is more clearly used than in the REDD program where climate change is the master narrative that articulates the possibilities for trading.

The logics informing public patrimonialization and the commoditization of nature are, in fact, similar and connected to the intellectual and economic framework of industrialization. In the industrialized societies of the late nineteenth century, gradually specializing in mass production and enduring higher levels of urban pollution, nature became a scarce and remote element: an element that the affluent layers of these societies soon started to appreciate (Plumb 1973). Over the centuries the wealthy strata of these industrial societies, the leisure class, consumed in livelihoods where the investment of capital was only marginally devoted to subsistence, and was in large part intended to signal status through taste (Veblen [1899] 1998; Bourdieu 1984). The Fordist revolution of the 1920s democratized access to goods, making possible a society of mass consumption (Cross 1996; Galbraith 1993). The creation of a consumerist society also democratized and opened access to nature as yet another good. Tourism became a generalized phenomenon, as a main sector of a leisure economy that dominated nature as a contemplative commodity. Nature, which has always been at the center of the disciplines and practices of the self (Foucault 1988), became not only a place of relaxation or excitement, but also a desirable 'thing' worth paying money for. Important tourist infrastructure networks and notions of beauty and health associated with environmentally-based leisure were created in these early moments of modern tourism. The Fordist revolution and the development of the idea that mass production should be accompanied by an equal mass consumption, resulted in an opening of the leisure economy to other social groups (MacCannell 1999). Mass production, of cars or tourist sites, has an inherent homogenizing - totalitarian - effect on taste and behavior at productive but also consumption levels (Horkheimer and Adorno 2007). This 'massification' and 'democratization' of leisure access coincided with the post Second World War economic boom (Bell 1973). Once nature was integrated as a good into the market, it experienced a process of fetishization, an abstraction as both image and value (Carrier and Macleod 2005).

After the 1960s and 1970s many enriched urban areas started to pay attention to the idea of quality of life, to the need to deal with pollution, and to protect the environment. The birth and consolidation of modern environmentalism as a mainstream ideological feature of Western societies coincides with the emergence of a society in which assuring food and shelter was no longer a significant struggle. Western societies do not enter into a postmodern age á la Lyotard (1984) or Jameson (1992) that, in a paradigmatic shift, questions the main tenets of modernity (state, market, monetization, mass production and consumption). If anything, these societies accelerate their hegemonic model and enter into a hyper-consumptive modern era (Charles and Lipovetsky 2005; Lipovetsky 2007; Virilio 2000). Industrialization is externalized to peripheral regions or developing countries where labor costs are lower and environmental regulations minimal. Post-industrial societies become dominated by post-materialistic values (Giddens 1995; Inglehart 1997). Affluence, in postscarcity situations and among the elite classes, generates post-materialistic priorities including different forms of leisure and environmentalism (Galbraith 1999). Hyper-modernity is dominated by the services industries, including leisure (Nazareth 2007). Environmentalism, not in its current contemplative form, but as sustainable use of the local resources of the community, was (and still often is) found across the globe (Guha 1999; Martinez-Alier 2002).

A commercial potential has pushed conservation, a field traditionally dominated by public institutions, science and collective heritage ideals, into a dialogue with private operators (Arsel and Büscher 2012; Pawliczek and Sullivan 2011). In this neoliberal approach nature is extracted from the public domain and becomes yet another commodity interacting in a multifactorial market in which conservation, extraction, or gentrification have similar standing (Igoe and Brockington 2007). Needless to sav, the irruption on the conservation effort of economically powerful external actors with maximizing goals - in the capitalist sense unbounded by public institutional limitations has increased the potential for local disempowerment and environmental injustice (Büscher et al. 2011; MacDonald 2010). This neoliberalization of the conservationist market unfolds amidst an emerging multiplicity of social agents: the national public institutions develop intricate networks and relationships with the international NGO complex, and the corporations interacting with them (Corson 2011; Sullivan 2012; Zanotti 2011).

The explanation of the transformation of nature into a fetishized commodity cannot be explained without a parallel discussion of changes to its image and the message that it conveys. Nature cannot be integrated as a commodity into the market without a message, a selling point. The integration of the "natural experience" and all that it selectively entails in "the habitus" (Bourdieu 1984) of different social and cultural levels of the Western societies has occurred through the slow massaging of the idea of nature. The idea has progressed from an irrelevant category to becoming a fundamental individual and collective right, from a place of danger to a place of leisure and pleasure, spectacle and alienation (Debord 1995), simulated experience (Baudillard 1994), desire (Deleuze and Guattari 1983), and nostalgia (Lipovetsky 2007). 


\section{Taste: culture and conservation}

The emergence of the western environmental paradigm at the end of the nineteenth century gradually transformed certain natural environments, at home and abroad, from wasteland to a valuable collective good (Arnold 1996; Dwyer 1996; Wark 1994). Nature went from hostile background to national patrimony or consumable item. It was subject to both narratives: commoditization and the national imagination, and, consequently, entered into the field of public policy activity (Cronon 1983; Ellen and Fukui 1996). The cultural transformations connected with this shift in taste took place at several levels. Landscape was reconceptualised (Cronon 1996; Darby 2000; Greenough and Tsing 2003), but also other actors and resources, for instance animals, are no longer considered vermin or utilitarian creatures, but were reshaped as icons (Philo and Wilbert 2000; Whatmore and Thorne 1998; Wolch and Emel 1998).

These taste changes, combined with an expansion of consumerism, allowed nature to become a commodity of a first order liable to generate benefits through tourism, trade, and the industry of leisure in general (Baudrillard 1998, Cross 1993; Stearns 2001). Patrimonialized nature became a commodity susceptible to intrinsic value and into the market. In a globalized world, the expansion, or the communication of productive, political, consumerist values back and forth between the global north and south results in international unequal distributions of wealth (Harvey 1989; Smith 2008) but also generates cultural dialogues (Gupta 1998; Hannerz 1996). Hypermodern capitalism is about capital mobility -the never-ending quest for lower costs of production - and cultural expectations associated with the ephemeral connections to international market economies (Ferguson 1999; Holmes 1989; Vaccaro 2010).

This political and economic process has also had symbolic consequences for the societies that have adopted the modern conservationist paradigm. The analysis of conservation requires an understanding of the territorial, institutional, and cultural assemblage that it promotes (Escobar 2008; Latour 2007; Ong and Collier 2004; Sassen 2006). Modern states are of urban origin and the majority of their constituencies are urban too. The values that they upheld, then, are the ones that dominate amongst urban elites and urban populations, their constituencies and beneficiaries. The legitimacy behind public conservation is dualistic: it defends a collective good, and it is informed by socially dominant and culturally hegemonic values. Environmentalism is one of these ideological characteristics that slowly, starting at the end of the nineteenth century, spread until it became mainstream (Guha 1999). Elites in the Third World emulate the trends proposed by First World elites. The environmental values of the elites in turn marginalize cultural identities in subaltern groups (Murray Li 2007; Scott 1998). Interventions into the non-urban areas of the nation and the world, comparable to internal or external colonialism, achieved legitimacy by the use of specialized, scientific (erao rational) knowledge, allegedly superior to its local counterpart (Fisher 2002; Guha 1997; Robbins 2000). This conflictive relationship often results in the emergence of different forms of resistance to the conservation policies - local, overt or subdued (Cullen 2012; Guha 1989; Scott 1976, 1985). These forms of resistance are the consequence of the conflictual interactions between different moral economies and culturally dependent ethical codes associated, in this case, with socially acceptable political, economic, and environmental behavior (Thompson 1968; Sivaramakrishnan 2005).

The modern idealization of nature affects much more than empty forests, marshes, and mountains. More often than not, the protection of these 'natures' is achieved by economically and culturally reorganizing rural areas. This reorganization, although largely based on urban social and cultural values, occurs in several domains: administrative (the creation of jurisdictional borders), infrastructural (services, housing, and roads needed to manage and satisfy tourism), demographic (changes to population movements), economic (shifts in the productive structures of the area towards the service economy). The proliferation of protected areas results in an indirect structural urbanization of the rural world (Lefebvre 1992; Williams 1973). The new rural areas are the result of the interaction of different collective imaginations and new markets (Vaccaro and Beltran 2007). In this new world order, these new 'natural' rural areas do also add value to their agricultural production by marketing to the organic and traditional food sectors, by adding a natural and cultural brand to their production (Piermattei 2013).

Protected areas, as new poles of attraction and development, are at the heart of processes of gentrification and selective urbanization (Prados 2009). The increase in the value of land, of landscape and of ways of life often results in cultural conflict (Duncan and Duncan 2004; Boglioli 2009), or in marginalization of locals and their access to the land and its natural resources (Phillips 2005; Stoddart 2012). The gentrification of the environment is not limited to a given national territory. On a world scale, there is a demand for nature as a scarce, highly valued commodity, and the peripheral rural areas have an abundance of it, which makes them sought after by affluent urban populations. The rural areas are consequently connected and integrated into regional, national and international management schemes and markets (Ensminger 1992; Godov 2001; Peters 1994). This integration does not happen without economic, infrastructural and cultural transformations (Castells 1996; Hannerz 1996).

The (bourgeois/elite) idealization of nature as a place untouched by the human hand (Braun and Castree 1998; Cronon 1996) adds to nature a veneer of authenticity (Roigé and Frigolé 2011) that has an 
interesting collateral effect. Protection often goes hand in hand with restoration efforts that attempt to simulate a pre-human nature. Protected areas, to different degrees, attempt to replicate an idealized nature (Peet and Watts 1996; Knight 2006) and managers seek to restore or recreate ideal natures (Barrett and White 2001; Castree 1995; Howell et al. 2011). Grounded in an Arcadian imaginary, restoration, reforestation, and related conservation projects are often much more about mimicking ideals (Auerbach 2004 [1942]; Baudrillard 1998; Vaccaro and Beltran 2009) than about managing real environmental change.

\section{Conclusion}

In their early work, political ecologists referred to 'natural resources' rather than 'nature' (Bryant and Bailey 1997). The goal was to avoid conceptual essentialisms and to bring economy and politics into the discussion: to create a political economy of the environment (Wolf 1972). The analysis of the politicization and commoditization of nature has been a common and relevant approach for the understanding of how the extractive and transformative industries operate. For centuries the elites of different societies and regimes acknowledged and used the 'leisure potential' of nature (Darby 2000). It was only during the modernization of Western societies, with the unfolding of the nation state and the capitalist mass market (Polanyi 1944), that nature was integrated definitively into the services sector via the creation of a large conservation apparatus (Peet and Watts 1996). This process resulted in an institutionalization (politics), commoditization (economy), and homogenization (culture) of the relationship between nature and society. A political economy of nature, of conservation, was created.

To reflect on this socialization of nature as an entity worth protecting, this article summarized two important elements of the literature on the political ecology of conservation: its historical chronologies and its conceptual genealogies. The rather extensive bibliography that accompanies this piece constitutes a fourth quasi-section. It attempts to offer an extensive dataset of entries associated with the political ecology of conservation and to concepts used by the social sciences analyzing conservation. This bibliographical task is so vast that we cannot claim to have included everything. We have, however, incorporated enough to give a good idea of the field for scholars and students alike.

The second section has two goals. The first goal is to offer a summary chronology of the different types of conservation that have been developed during the modern era: fortress, participatory, and neoliberal conservation. This three stage sequence is, of course, a construct. Although the three types emerged in historical succession, none of them disappears when the others emerge. Rather they overlap or cohabit in different localities in different periods, with an emphasis on one or the other depending on the vagaries of management in that particular period. The second goal of this chronological section is to show the similarities between the type of conservation practiced and the society that implements it. The fortress conservation model emerges in a moment in which colonialism, with remote authoritarian institutional control, is dominant. The neoliberal conservationist model does not appear until the Reagan-Thatcher period achieved its current mature form and became the hegemonic international political framework.

The third section focuses on the intellectual genealogies of some of the most relevant concepts needed in discussing the architecture of conservation. To achieve this we subdivided this section into three: state, market, and culture. In the subsection devoted to the state we discussed, amongst many others, ideas such as governmentality, territoriality, bureaucracy, legitimacy, knowledge, power, environmentality, state-making, and resistance. In the subsection devoted to the capitalist market we connected the elements introduced in the previous section to others including the leisure class, the leisure economy, mass production, market integration, networks, Fordism, hyper-consumption, commoditization, and the moral economy. We finished by mapping cultural shifts: identifying hypermodernity, postmaterialistic values, desire, spectacle, patrimonialization, heritage, collective identity, taste, and globalization.

We have attempted to bring together a large group of concepts and authors coming from different fields of social sciences and humanities that are not often put together on the same page. The goal is to highlight the connections that exist between them in their relation to the general field of conservation, identifying the intellectual network created by several generations of social scientists. It must be acknowledged that this literature review of political ecology and conservation does not include a survey of the gray literature comprising on-the-ground evaluation reports from the conservation management organizations. A significant percentage of these reports are produced by social scientists too. This is a daunting task, necessary to complete the picture of the relationship between social sciences and the conservation world, but that deserves a full article for itself.

In the last couple of decades, then, critical studies of conservation have blossomed. They have succeeded in establishing a dialogue with ecology and conservation biology, so that many of the most relevant concepts used by the social sciences and humanities are now shared. However, this intellectual production is not having a similar influence on conservation policies, design, and management in the field. Most conservation practitioners have been unable to address the political ecology critique. Although conservationist discourses have integrated 'social concerns' to some extent, the everyday reality of 
conservation policies is often marked by an antagonistic interaction between those policies and local people. Critical political ecology has much to contribute to the practice, as well as the theory, of environmental conservation. It is a difficult task, one still pending, to convince biologists and politicians that these critiques are constructive and have the potential to improve local wellbeing and environmental conservation. To realize this potential two things must happen: first, the conservationist world must be more receptive to the obvious fact that ecology and society cannot be understood or managed independently, and that governance mechanisms have political, social, and ecological consequences that might question or improve the long term viability of public policy. Secondly, political ecology scholars must make an effort to make our discourses, ideas, and contributions available to people who speak other academic and non-academic dialects and hold different moral economies. Ironically, we have not being so good at doing that.

\section{References}

Adams, W.M. and J. Hutton. 2007. People, parks and poverty: political ecology and biodiversity conservation. Conservation and Society 5 (2): 147-183.

Agrawal, A. 1996. Greener pastures: politics, markets and community among a migrant pastoral people. Durham: Duke University Press.

Agrawal, A. 2005. Environmentality: technologies of government and the making of subjects. Durham: Duke University Press.

Agrawal, A. and K. Redford. 2009. Conservation and displacement: an overview. Conservation and Society 7: 1-10.

Anderson, B. 1983. Imagined communities: reflections on the origin and spread of nationalism. New York: Verso.

Anderson, D. and E. Berglund, (eds.) 2003. Ethnographies of conservation: environmentalism and the distribution of privilege. New York: Berghahn Books.

Appadurai, A. 1996. Modernity at large: cultural dimensions of globalization. Minneapolis: University of Minnesota Press.

Argyrou, V. 2005. The logic of environmentalism: anthropology, ecology and postcoloniality. New York: Berghahn Books.

Arnold, D. 1996. The problem of nature: environment, culture, and European expansion. Oxford: Blackwell.

Arsel, M. and B. Büscher. 2012. NatureTM Inc.: changes and continuities in neoliberal conservation and market-based environmental policy. Development and Change 43 (1): 53-78.

Auerbach, E. 2003 [1942] Mimesis: the representation of reality in Western literature. Princeton: Princeton University Press.

Augé, M. 1999. An anthropology for contemporaneous worlds. Stanford: Stanford University Press.

Balée, W. 2006. The research program of historical ecology. Annual Review of Anthropology 35: 75-98.

Barrett, L. and D. White. 2001. The reconstruction of nature: postmodern ecology and the Kissimmee River Restoration Project. Critical Studies 22: 229-250.

Batisse, M. 1982. The biosphere reserve: a tool for environmental conservation and management. Environmental Conservation 9(2): 101-112.

Baudrillard, J. 1994. Simulacra and simulation. Ann Arbor: University of Michigan Press.

Baudrillard, J. 1998. Consumer society: myths and structures. London: Sage.

Bell, D. 1973. The coming of the post-industrial society. New York: Basic Books.

Beltran, O. 2012. La naturaleza en venta. Imágenes culturales y mercado en el turismo amazónico del Sur del Perú. In Valcuende, J. M. (ed.) Amazonía. Viajeros, turistas y poblaciones indígenas. Tenerife: Pasos. Pp 123-154.

Bergin, A. 1993. A rising tide of Aboriginal sea claims: implications of the Mabo case in Australia. The International Journal of Marine and Coastal Law 8(3):359-371.

Berkes, F. 2008. Community conserved areas: policy issues in historic and contemporary context. Conservation Letters 2:19-24.

Berkes, F. and D. Jolly. 2001. Adapting to climate change: social-ecological resilience in a Canadian Western Arctic community. Conservation Ecology 5 (2): 18. (now Ecology \& Society)

Blaikie, P. 1985. The political economy of soil erosion in developing countries. Longman: London.

Blaikie, P. 2006. Is Small Really Beautiful? Community-based Natural Resource Management in Malawi and Botswana. World Development 34 (11): 1942-1957.

Boglioli, M. 2009. A matter of life and death: hunting in contemporary Vermont. Boston: University of Massachusetts Press. 
Borgerhoff-Mulder, M. and P. Copolillo. 2004. Conservation: linking ecology, economics, and culture. Princeton: Princeton University Press.

Bourdieu, Pierre. 1984. Distinction: a social critique of the judgement of taste. London: Routledge.

Braun, B. and N. Castree (eds.) 1998. Remaking reality: nature at the millennium. London: Routledge.

Brechin, S., Wilshusen, P., Fortwrangler, C., and P. West, (eds.) 2003. Contested nature: promoting international biodiversity conservation with social justice in the twenty-first century. New York: State University of New York Press.

Brockington, D. 2002 Fortress conservation: the preservation of the Mkomazi Game Reserve, Tanzania. Oxford: James Currey.

Brockington, D., R. Duffy, and J. Igoe (eds.) 2008. Nature unbound: conservation, capitalism and the future of protected areas. London: Routledge.

Brockington, D. and R. Duffy (eds.). 2011. Capitalism and conservation. London: Wiley-Blackwell.

Bromley, D. 1991. Environment and economy: property rights and public policy. Oxford: Basil Blackwell.

Bromley, D. 1992. Making the commons work: theory, practice, and policy. San Francisco: ICS Press.

Brosius, P. and D. Russell. 2003. Conservation from above: an anthropological perspective on transboundary protected areas and ecoregional planning. In Goodale, U. et al. Transboundary protected areas: the viability of regional conservation strategies. New York: Food Products Press. Pp 39-66.

Brosius, P., Tsing, A., and C. Zerner, (eds.) 2005. Communities and conservation: histories and politics of community-based natural resource management. New York: Altamira.

Bryant R. and S. Bailey. 1997. Third world political ecology: an introduction. London: Routledge.

Büscher, B. and W. Dressler 2007. Linking neoprotectionism and environmental governance: on the rapidly increasing tensions between actors in the environment-development nexus. Conservation and Society 5(4):586-611.

Büscher, B, Sullivan, S., Neves, K., Igoe, J., and D. Brockington. 2011. Towards a synthesized critique of neoliberal biodiversity conservation. Capitalism Nature Socialism 23 (2): 4-30.

Carney, J. and M.J. Watts. 1991. Disciplining women? Rice, mechanization, and the evolution of Mandinka gender relations in Senegambia. Signs 16 (4): 651-681.

Carrier, J. and G. Macleod. 2005. Bursting the bubble: the socio-cultural context of ecotourism. Journal of the Royal Anthropological Institute 11:315-334.

Carrier, J. and P. West. 2009. Virtualism, governance and practice: vision and execution in environmental conservation. New York: Berghahn.

Carruthers, J. 1995. The Kruger National Park: a social and political history. Pietermaritzburg, South Africa: University of Natal Press.

Castells, M. 1996. The rise of the network society. Malden: Blackwell Publishers.

Castree, N. 1995. The nature of produced nature. Antipode 27:12-48.

Castree, N. 2003. Commodifying what nature? Progress in Human Geography 27 (3): 273-297.

Cederlof, G. and K. Sivaramakrishnan (eds.) 2006. Ecological nationalisms: nature, livelihoods and identities in Southeast Asia. Seattle: University of Washington Press.

Chapin, M. 2004. A challenge to conservationists. World Watch 17-31. Responses

Charles, S. and G. Lipovetsky. 2005. Hypermodern times. New York: Polity.

Cinner, J. and S. Aswani. 2007. Integrating customary management into marine conservation. Biological Conservation 140 (3-4): 201-216.

Cooper, M. 2010. Turbulent worlds: financial markets and environmental crises. Theory, Culture and Society 27 (2-3): 167-190.

Cooper, N. 2000. How natural is a nature reserve? An ideological study of British nature conservation landscapes. Biodiversity and Conservation 8:1131-1152.

Corson, C. 2010. Tracing the origins of neoliberal conservation through the U.S. Agency for International Development. Antipode 42(3):576-602.

Corson, C. 2011. Shifting environmental governance in a neoliberal world: U.S. AID for conservation. In Brockington, D. and R. Duffy (eds.). Capitalism and conservation. London: Wiley-Blackwell.

Craib, R. 2004. Cartographic Mexico: a history of state fixations and fugitive landscapes. Durham: Duke University Press.

Cronon, W. 1983.Changes in the land: Indians, colonists, and the ecology of New England. New York: Hill and Wang. 
Cronon, W. (ed.) 1996 Uncommon ground: rethinking the human place in nature. New York: Norton.

Cross, G. 1993. Time and money: the making of consumer culture. London: Routledge.

Cullen, A. 2012. The political ecology of land tenure in Timor Leste: environmental contestation and livelihood impacts in the Nino Konis Santana National Park. In M. Leach, N. Canas Mendes, A.B. da Silva, B. Boughton and A. daCosta Ximenes (eds.) Peskiza foun kona ba / Novas investigações sobre / New Research on / Penelitian Baru mengenai Timor-Leste. Hawthorn: Swinburne Press. Pp158-165.

Darby, W. 2000.Landscape and identity: geographies of nation and class in England. Oxford: Berg.

Davallon, J. 2006. Le don du patrimoine: une approche comunicationelle de la patrimonialisation. Paris: Hermès Sciences-Lavoisier.

Dean, M. 1999. Governmentality: power and rule in modern society. London: Sage.

Debord G. 1995 [1967] Society of the spectacle. New York: Zone Books

Delaney, D. 2005. Territory: a short introduction. Oxford: Blackwell.

Deleuze, G. and F. Guattari. 1983. Anti-Oedipus machine: capitalism and schizophrenia. Minneapolis: University of Minnesota Press.

Dove, M. 2006. Indigenous knowledge and environmental politics. Annual Review of Anthropology 35:191208.

Duffy, R. 1997. The environmental challenge to the nation-state: superparks and national parks policy in Zimbabwe. Journal of Southern African Studies 23(3)441-511.

Duffy, R. 2010. Nature crime: how we're getting conservation wrong. New Haven: Yale University Press.

Duncan, J. and N. Duncan. 2004. Landscapes of privilege: the politics of the aesthetic in an American suburb. New York: Routledge.

Dwyer, P.D. 1996. The invention of nature. In R. F. Ellen and K. Fukui (eds.) Redefining nature: ecology, culture and domestication. Oxford: Berg.

Ellen R. and K. Fukui (eds.) 1996. Redefining nature: ecology, culture and domestication. Oxford: Berg.

Ensminger, J. 1992. Making a market: the institutional transformation of an African society. Cambridge: Cambridge University Press.

Escobar, A. 1995. Encountering development: the making and unmaking of the third world. Princeton: Princeton University Press.

Escobar, A. 1998. Whose knowledge, whose nature? biodiversity, conservation, and the political ecology of social movements. Journal of Political Ecology 5: 53-82.

Escobar, A. 2008. Territories of difference: place, movements, life, redes. Durham N.C.: Duke University Press. Review

Europark. 2008. Procedure for assigning IUCN Protected Area Management categories. Madrid: EuroparkSpain.

Fabricius, C., Koch, E., Magome, H., and S. Turner. 2004. Rights, resources and rural development: community-based natural resource management in Southern Africa. London: Earthscan.

Fairhead, J. and M. Leach. 1996. Misreading the African landscape: society and ecology in the forestsavannna mosaic. Cambridge: Cambridge University Press.

Feld, S. and K. Basso (eds.) 1996. Senses of place. Santa Fe, New Mexico: School of American Research Press.

Ferguson, J. 1999. Expectations of modernity: myths and meanings of urban life on the Zambian Copperbelt. Berkeley: University of California Press.

Fisher, F. 2002. Citizens, experts, and the environment: the politics of local knowledge. Durham: Duke University Press.

Floyd, M. 2001. Managing national parks in a multicultural society: searching for common ground. Managing Recreational Use 18 (3): 41-52.

Forsyth, T. 2002. Critical political ecology. the politics of environmental science. New York: Routledge.

Fortwangler, C.2007. Friends with money: private support for a national park in the US Virgin Islands. Conservation and Society 5(4):504-533.

Foucault, M. 1988. Technologies of the self. Boston: University of Massachusetts Press.

Foucault, M. 2007. Security, territory, population: lectures at the Collège de France 1977-1978. New York: Palgrave McMillan.

Foucault, M. 2008. The birth of biopolitics: lectures at the Collège de France 1978-1979. New York: Palgrave MacMillan.

Galbraith, J. K. 1993. The society of contentment. Boston: Mariner Books. 
Galbraith, J. K. 1999. The affluent society. New York: Penguin Book.

Gellner, E. 1983. Nations and nationalism. Oxford: Blackwell.

Gibson, C. 1999. Politicians and poachers: the political economy of wildlife policy in Africa. Cambridge: Cambridge University Press.

Gibson, C. and S. Marks. 1995. Transforming rural hunters into conservationists: an assessment of community-based wildlife management programs in Africa. World Development 23: 941-957.

Giddens, A. 1995. Affluence, poverty and the idea of a post-scarcity society. UNRISD Discussion Papers 63. Geneva: UNRISD.

Godoy, R. 2001. Indians, rain forests, and markets: theory, methods, and analysis. New York: Columbia University Press.

Goldman, M. 2006. Imperial nature: the World Bank and struggles for social justice in the age of globalization. New Haven: Yale University Press.

Gramsci, A. 2011. The prison notebooks. New York: Columbia University Press.

Greenough, P. and A. Tsing (eds.) 2003. Nature in the global south: environmental projects in South and Southeast Asia. Durham: Duke University Press.

Griffiths, T. and L. Robin. 1997. Ecology and empire: environmental history of settler societies. Keele UK: Keele University Press.

Grove, R. 1995. Green imperialism: colonial expansion, tropical island edens and the origins of environmentalism 1600-1860. Cambridge: Cambridge University Press.

Guha, R. 1997. The authoritarian biologist and the arrogance of anti-humanism: conservation in the Third World. The Ecologist 27(1): 14-20.

Guha, R. 1999. Environmentalism: a global history. New York: Longman.

Guha, R. 2000. The unquiet woods: ecological change and peasant resistance in the Himalaya. Berkeley: University of California Press.

Gupta, A. 1998. Postcolonial developments: agriculture in the making in modern India. Durham: Duke University Press.

Haenn, N. 2005. Fields of power, forests of discontent: culture, conservation, and the state in Mexico. Tucson: Arizona University Press.

Hann, C. and the Property Relations Group. 2003. The postsocialist agrarian question. New Brunswick: Transaction Publishers.

Hannah, M. 2000. Governmentality and the mastery of the territory in nineteenth-century America. Cambridge: Cambridge University Press.

Hannerz, U. 1996. Transnational connections: culture, people, places. London: Routledge.

Hardin, R. 2011. Concessionary politics: property, patronage and political rivalry in central African forest management. Current Anthropology 52 (S3): S113-S125.

Harvey, D. 1989. The condition of postmodernity: an enquiry into the origins of cultural change. Oxford: Blackwell.

Harvey, D. 2001. Spaces of capital: towards a critical geography. Edinburgh: Edinburgh University Press.

Harvey, C..A. Dickson, B., and C. Kormos. 2009. Opportunities for achieving biodiversity conservation through REDD. Conservation Letters 3(1): 53-61.

Hayden, C. 2003. When nature goes public: the making and unmaking of bioprospecting in Mexico. Princeton: Princeton University Press.

Heatherington, T. 2010. Wild Sardinia: indigeneity and the global dreamtimes of environmentalism. Seattle: University of Washington Press.

Heynen N., McCarthy J., Prudham, S. and P. Robbins (eds.). 2007. Neoliberal environments: false promises and unnatural consequences. London: Routledge. Introduction

Hirsch, E. and M. O'Hanlon. (eds.) 1995. The anthropology of landscape: perspectives on place and space. Oxford: Clarendon Press.

Holmes, D. 1989. Cultural disenchantments: worker peasantries in northeast Italy. Princeton, NJ: Princeton University Press.

Holmes, G. 2011. Conservation's friends in high places: neoliberalism, networks, and the transnational conservation elite. Global Environmental Politics 11(4):1-21.

Holmes, G. 2012. Biodiversity for billionaires: capitalism, conservation and the role of philanthropy in saving/selling nature. Development and Change 43(1): 185-203. 
Horkheimer, M. and T. Adorno. 2007 [1944]. Dialectics of the enlightenment. Stanford: Stanford University Press.

Howell, E., Harrington, J. and S. Glass 2011. Introduction to restoration ecology. Washington: Island Press.

Hunn, E. 2008. A Zapotec natural history: trees, herbs and flowers, birds, beasts and bugs in the life of San Juan Gbëë. Tucson: University of Arizona Press.

Igoe, J. 2003. Conservation and globalization: a study of national parks and indigenous communities from East Africa to South Dakota. Belmont, CA: Wadsworth Publishers.

Igoe, J. 2010. The spectacle of nature in the global economy of appearances: anthropological engagements with the spectacular mediations of transnational conservation. Critique of Anthropology 30(4):375397.

Igoe, J. and D. Brockington. 2007. Neoliberal conservation: a brief introduction. Conservation and Society 5(4):432-449.

Igoe, J. and B. Croucher. 2007. Conservation, commerce, and communities: the story of community-based wildlife management areas in Tanzania's northern tourist circuit. Conservation and Society 5(4): 534561.

Inglehart, R. 1997. Modernization and postmodernization: cultural, economic, and political change in fortythree societies. Princeton: Princeton University Press.

Jameson, F. 1992. Postmodernism, or, the cultural logic of late capitalism. Durham: Duke University Press.

Knight, J. 2006. Waiting for wolves in Japan: an anthropological study of people-wildlife relations. Honolulu: University of Hawai'i Press.

Kosoy N and Corbera E (2010) Payments for ecosystem services as commodity fetishism. Ecological Economics 69(6):1228-1236

Lai, F. 2013. Nature and the city: the salt-works park in the urban area of Cagliari (Sardinia, Italy). Journal of Political Ecology 20: in press

Langholz, J. 2003. Privatizing conservation. In Brechin, S., P. Wilshusen, P. West, and C. Fortwangler, (eds.) Contested nature: promoting international biodiversity with social justice in the 21st century. New York: State University of New York Press. Pp 117-135.

Langton, M.L., Z.M. Rhea and L.R. Palmer. 2005. Community-oriented protected areas for Indigenous peoples and local communities. Journal of Political Ecology 12: 23-50.

Latour, B. 2007. Reassembling the social: an introduction to actor-network-theory. Oxford: Oxford University Press.

Lausche, B. 2012. Guidelines for protected areas legislation. Bonn/Gland: IUCN.

Lefebvre, H. 1992. The production of space. London: Wiley Blackwell.

Lewis, H. 1989. Ecological and technological knowledge of fire: aborigines versus park rangers in Northern Australia. American Anthropologist (91):940-961.

Lipovetsky, G. 2007. La felicidad paradojica. Barcelona: Anagrama.

Lowe, C. 2004. Making the monkey: how the Togean Macaque went from 'new form' to 'endemic species' in Indonesian conservation biology. Cultural Anthropology 19(4): 491-516.

Lowe, C. 2006. Wild profusion: biodiversity conservation in an Indonesian archipelago. Princeton: Princeton University Press.

Lyotard, J. F. 1984. The postmodern condition: a report on knowledge. Minneapolis: University of Minnesota Press.

MacCannell, D. 1999. The tourist: a new theory of the leisure class. Berkeley: University of California Press.

MacDonald, K. 2010. The devil is in the (bio)diversity: private sector "engagement" and the restructuring of biodiversity conservation. Antipode 42(3):513-550.

MacKenzie, J. 1988. The empire of nature: hunting, conservation and British imperialism. Manchester: Manchester University Press.

Martinez-Alier, J. 2002. The environmentalism of the poor. Johannesburg: United Nations Research Institute for Social Development (UNRISD) and University of Witwatersrand.

Mathews, A. 2011. Instituting nature: authority, expertise, and power in Mexican forests. Boston: MIT Press.

McCarthy, J. and S. Prudham. 2004. Neoliberal nature and the nature of neoliberalism. Geoforum 35(3):27583.

Milton, K. 1996. Environmentalism and cultural theory: exploring the role of anthropology in environmental discourse. London: Routledge. 
Moore, D. 1998a. Clear waters and muddied histories: environmental history and the politics of community in Zimbabwe's Eastern Highlands. Journal of Southern African Studies 24(2):377-404.

Moore, D. 1998b. Subaltern struggles and the politics of place: remapping resistance in Zimbabwe's Eastern Highlands. Cultural Anthropology 13(3):344-382.

Münster' D. and U. Münster. 2012. Consuming the forest in an environment of crisis: nature tourism, forest conservation and neoliberal agriculture in South India. Development and Change 43(1):205-227.

Murray Li, T. 2007. The will to improve: governmentality, development, and the practices of politics. Durham: Duke University Press.

Nazareth, L. 2007. The leisure economy: how changing demographics, economics, and generational attitudes will reshape our lives and our industries. Ontario: John Wiley.

Neumann, R. 1992. Political ecology of wildlife conservation in the Mt. Meru Area of northeast Tanzania. Land Degradation and Rehabilitation 3:85-98.

Neumann, R. 1998. Imposing wilderness: struggles over livelihood and nature preservation in Africa. University of California Press, Berkeley.

Neumann, R. 2005. Making political ecology. Hodder Arnold, New York.

Nietschmann, B. 1973. Between land and water: the subsistence ecology of the Miskito Indians, Eastern Nicaragua. New York: Seminar Press.

Ong, A. and S. Collier. (eds.) 2004. Global assemblages: technology, politics, and ethics as anthropological problems. London: Wiley-Blackwell.

Orlove, B. 1980. Ecological anthropology. Annual Review of Anthropology 9:235-273.

Orlove, B. and S. Brush. 1996. Anthropology and the conservation of biodiversity. Annual Review of Anthropology 25:329-352.

Ostrom, E. 1990. Governing the commons: the evolution of institutions for collective action. Cambridge: Cambridge University Press.

Ostrom, E., Dietz, T., Dolsak, N., Stern, P., Stonich, S. and E. Weber. (eds.) 2002. The drama of the commons. Washington: National Academy Press.

Pawliczek, J. and S. Sullivan. 2011. Conservation and concealment in SpeciesBanking.com, USA: an analysis of neoliberal performance in the species offsetting industry. Environmental Conservation 38 (4): 435-444.

Peet, R. and M.J. Watts. (eds.) 1996. Liberation ecologies: environment, development, social movements. London: Routledge.

Pellizzoni, L. 2011. Governing though disorder: neoliberal environmental governance and social theory. Global Environmental Change 21 (3): 795-803.

Pels, P. 1997. The anthropology of colonialism: culture, history, and the emergence of western governmentality. Annual Review of Anthropology 26:163-183.

Peluso, N. 1992. Rich forests, poor people: forest access and control in Java. Berkeley: University of California Press.

Peluso, N. 1993. Coercing conservation: the politics of state resource control. Global Environmental Change 3(2): 199-218.

Peters, P. 1994. Dividing the commons: politics, policy and culture in Botswana. Charlottesville: University Press of Virginia.

Peters, J. 1998. Sharing national park entrance fees: forging new partnerships in Madagascar. Society and Natural Resources 11(5):517-530.

Peterson, R., Russell, D., West, P. and P. Brosius. 2010. Seeing (and doing) conservation through cultural lenses. Environmental Management 45(1):5-18.

Piermattei 2013. Local farmers vs. environmental universalism: conflicts over nature conservation in the Parco Nazionale dei Monti Sibillini, Italy. Journal of Political Ecology 20: in press.

Plumb, J. H. 1973. Use of leisure in eighteenth century England. Reading: University of Reading.

Polanyi, K. 1944. The great transformation. New York: Holt, Rinehart and Winston.

Posey, D. and M. Balick. 2006. Human impacts on Amazonia: the role of traditional ecological knowledge in conservation and development. New York: Columbia University Press.

Phillips, M. 2005. Rural gentrification and the production of nature: a case study from Middle England. Conference paper. Mexico City: International Conference of Critical Geographers. 
Philo, C. and C. Wilbert. (eds.) 2000. Animal spaces, beastly places: new geographies of human-animal relations. London: Routledge.

Prados, M. J. (ed.) 2009. Naturbanization: new identities and processes for rural-natural areas. Leiden: CRC Press.

Rademacher, A. and K. Sivaramakrishnan. (eds.) 2013. Ecologies of urbanism in India: metropolitan civility and sustainability. Hong Kong: Hong Kong University Press.

Rangajaran, M. 1996. Fencing the forest: conservation and ecological change in India's central provinces 1860-1914. Delhi: Oxford University Press.

Ranger, T. 1999. Voices from the rocks: nature, culture and history in the Matopos Hills of Zimbabwe. Bloomington: Indiana University Press.

Redford, K. and J. Mansour. (eds.) 1996. Traditional peoples and biodiversity conservation in large tropical landscapes. Arlington: America Verde Press.

Reid, H. 2001. Contractual national parks and the Makuleke community. Human Ecology 29(2):135-156.

Reid, C.T. 2011. The privatisation of biodiversity? Possible new approaches to nature conservation law in the UK. Journal of Environmental Law 23 (2): 203-231.

Robbins, P. 2000. The practical politics of knowing: state environmental knowledge and local political economy. Economic Geography 76(2): 126-44.

Robbins, P. 2004. Political ecology: a critical introduction. Oxford: Blackwell.

Robertson, M. 2006. The nature that capital can see: science, state, and market in the commodification of ecosystem services. Environment and Planning D: Society and Space 24:367-387.

Rocheleau, D., Thomas-Slayter, B. and E. Wangari. 1996. Feminist political ecology: global issues and local experience. London: Routledge.

Roigé, X. and J. Frigolé. (eds.) 2011.Constructing cultural and natural heritage: parks, museums, and rural heritage. Girona: Institutu Catala de la Recerca en Patrimoni Cultural.

Saberwal, V., Rangarajan, M. and A. Kothari. 2001. People, parks, and wildlife: towards coexistence. New Delhi: Orient.

Saberwal, V. and M. Rangarajan. (eds.) 2003. Battles over nature: science and the politics of conservation. New Delhi: Permanent Black.

Sachs, W. 1999. Planet dialectics. exploration in environment and development. London: Zed Books.

Sack, R. 1986. Human territoriality: its theory and history. London: Cambridge University Press.

Santamarina, B. 2008. Antropología y medio ambiente: revisión de una tradición y nuevas perspectivas de análisis en la problemática ecológica. Revista de Antropología Iberoamericana 3(2): 144-184.

Santamarina, B. 2009. On parks and nature: enunciations, foundations and mechanisms. Revista de Dialectologia y Tradiciones Populares LXIV (1): 297-324.

Sassen, S. 2006. Territory, authority, rights: from medieval to global assemblages. Princeton: Princeton University Press.

Scott, J. 1976. The moral economy of the peasant: rebellion and subsistence in Southeast Asia. Yale University Press: New Haven.

Scott, J. 1985. Weapons of the weak: everyday forms of peasant resistance. Yale University Press, New Haven.

Scott, J. 1998. Seeing like a state: how certain schemes to improve the human condition have failed. New Haven: Yale University Press.

Schlosberg, D. 2007. Defining environmental justice: theories, movements, and nature. Oxford University Press.

Sivaramakrishnan, K. 1999. Modern forests: statemaking and environmental change in colonial Eastern India. Stanford: Stanford University Press.

Sivaramakrishnan, K. 2005. Some intellectual genealogies for the concept of everyday resistance. American Anthropologist 107 (3): 346-355.

Smith, N. 2008. Uneven development: nature, capital and the production of space. Athens: University of Georgia Press.

Spence, M.D. 1996. Dispossessing the wilderness: Yosemite Indians and the national park ideal. Pacific Historical Review, 65:27-59.

Stearns, P. 2001. Consumerism in world history: the global transformation of desire. London: Routledge.

Steenkamp, C. 1998. The Makuleke land claim signing ceremony: harmonizing social justice and conservation. African Conservation 52(4):8-9. 
Stevens, S. (ed.) 1997. Conservation through cultural survival. Washington: Island Press.

Stoddart, M. 2012. Making meaning out of the mountains: the political ecology of skiing. Vancouver: University of British Columbia Press.

Storey, D. 2012. Territories: the claiming of space. London: Routledge.

Sullivan, S. 2009. Green capitalism and the cultural poverty of constructing nature as a service provider. Radical Anthropology 18-27.

Sullivan, S. 2010. 'Ecosystem Service Commodities' - a new imperial ecology? Implications for animist immanent ecologies, with Deleuze and Guattari. New Formations 69:111-128.

Sullivan, S. 2012. Banking nature? The spectacular financialisation of environmental conservation. Antipode 45(1):198-217. Preprint

Theodossopoulos, D. 2003. Troubles with turtles: cultural understandings of the environment on a Greek Island. New York: Berghahn Books.

Thompson, E.P. 1968. The making of the English working class. London: Peter Smith Publisher.

Toledo, V., Ortiz-Espejel, B., Cortés, L., Moguel, P., and M. de J. Ordoñez. 2003. The multiple use of tropical forests by indigenous peoples in Mexico: a case of adaptive management. Conservation Ecology 7(3): 9. (now Ecology \& Society)

Tsing, A. 2005. Friction: an ethnography of global connection. Princeton and Oxford: Princeton University Press.

UNESCO, 2012. Managing natural world heritage. Paris: UNESCO.

Vaccaro, I. 2005. Property mosaic and state-making: governmentality, expropriation and conservation in the Pyrenees. Journal of Ecological Anthropology 9: 4-19.

Vaccaro, I. 2010. Theorizing impending peripheries: postindustrial landscapes at the edge of hyper modernity's collapse. Journal of International and Global Studies 1(2): 22-44.

Vaccaro, I. and O. Beltran. 2007. Consuming space, nature and culture: patrimonial discussions in the hypermodern era. Journal of Tourism Geographies 9(3): 254-274.

Vaccaro, I. and O. Beltran. 2009. Livestock versus 'wild beasts': the contradictions of the natural patrimonialization of the Pyrenees. Geographical Review 99(4): 499-516.

Vandergeest, P. and N. Peluso. 1995. Territorialization and state power in Thailand. Theory and Society 24:385-426.

Vayda A. and B. Walters. 1999. Against political ecology. Human Ecology 27: 167-79

Veblen, T.. 1998 [1899]. The theory of the leisure class. New York: Prometheus Books.

Virilio, P. 2000. The information bomb. New York: Verso.

Walley, C.J. 2004. Rough waters: nature and development in an East African marine park. Princeton: Princeton University Press.

Wark, McK.1994. Third nature. Cultural Studies 8(1): 115-132.

WCED. 1987. Our common future. Oxford: Oxford University Press.

Weber, M. 2011 [1904]. The methodology of the social sciences. New York: Transaction Publishers.

West, P. and S. Brechin (eds.) 1991. Resident peoples and national parks: social dilemmas and strategies in international conservation. Tucson: University of Arizona Press.

West, P. 2005. Translation, value, and space: theorizing an ethnographic and engaged environmental anthropology. American Anthropologist 107(4):632-642.

West, P. 2006. Conservation is our government now: the politics of ecology in Papua New Guinea. Durham: Duke University Press.

West, P., Igoe, J. and D. Brockington. 2006. Parks and peoples: the social impact of protected areas. Annual Review of Anthropology 35:251-277.

Western, D. and M. Wright. (eds.) 1994. Natural connections: perspectives in community-based conservation. Washington: Island Press.

Whatmore, S. and L. Thorne. 1998. Wild(er)ness: reconfiguring the geographies of wildlife. Transactions of the Institute of British Geographers 23:435-454.

Wilshusen, P., Brechin, S., Fortwrangler, C. and P. West. 2002. Reinventing a square wheel: critique of a resurgent "protection paradigm" in international biodiversity conservation. Society and Natural Resources 15: 17-40.

Wilshusen, P. 2010. The receiving end of reform: everyday responses to neoliberalization in southeastern Mexico. Antipode 42(3): 767-799.

Williams, R. 1973. The country and the city. New York: Oxford University Press. 
Winichakul, T. 1997. Siam mapped: a history of the geo-body of a nation. Manoa: University of Hawaii Press.

Wolch, J. and J. Emel. 1998. Animal geographies: place, politics and identity in the nature-culture borderlands. London: Verso.

Wolf, E. 1972. Ownership and political ecology. Anthropology Quarterly 45 (3): 201-205.

Woods, N. 2007. The globalizers: the IMF, the World Bank, and their borrowers. Ithaca: Cornell University Press.

Zanotti, L. 2011. The politics of possession: the proliferation of partnerships in the Brazilian Amazon. Political and Legal Anthropology Review 34(2): 290-314.

Zimmerer, K. (ed.) 2006. Globalization and new geographies of conservation. Chicago: University of Chicago Press.

\begin{abstract}
This article explicitly connects a growing body of specific literature, the political ecology of conservation, to some of the often overlooked, main conceptual components emerging from political anthropology and geography (sources of legitimacy, governmentality, territoriality, or state making), political economy (commoditization, market integration, niche markets, or gentrification), and cultural studies of the environment (cultural transformations of nature, cultural heritage and landscapes, taste, and identity politics). All these concepts and literary fields are at the basis of the contemporary social analysis of conservation policies and their consequences. The article also provides an updated large bibliography on the concepts potentially relevant to a political ecology of conservation.
\end{abstract}

Key Words: conservation, governmentality, taste, nature, commoditization of nature, territoriality

\title{
Résumé
}

Cet article relie de manière explicite un corpus littéraire spécifique qui ne cesse de croître, l'écologie politique de la conservation, à ses composantes conceptuelles parfois négligées, telles qu'elles émergent de l'anthropologie politique et de la géographie (questions de légitimité, gouvernementalité, territorialité, étatisation), de l'économie politique (marchandisation, intégration des marchés, marchés de niche, embourgeoisement) et des études culturelles environnementales (transformation culturelle de la nature, patrimoine culturel et paysage, goût et politiques identitaires). Tous ces concepts et champs littéraires se trouvent au fondement de l'analyse sociale des politiques de la conservation et de leurs conséquences telle qu'elle se pratique aujourd'hui. Cet article fournit également une importante bibliographie mise à jour en ce qui a trait aux concepts pertinents à l'écologie politique de la conservation.

Mots clés: conservation, gouvernementalité, goût, nature, marchandisation de la nature, territorialité

\section{Resumen}

Este artículo conecta de manera explícita un creciente campo de literatura, la ecología política de la conservación, con algunos de los componentes teóricos, a menudo ignorados, que emergen de la antropología y la geografía política (Fuentes de legitimidad, gubernamentalidad, territorialidad, construcción estatal), economía política (mercantilización, integración de mercado, mercados especializados, o gentrificación), v estudios culturales del medioambiente (transformaciones culturales de la naturaleza, patrimonio cultural y paisaies, preferencias, e identidades políticas). Todos estos conceptos y campos temáticos están en la base de los análisis sociales contemporáneos de las políticas de conservación y sus consecuencias. Este artículo, además, ofrece una amplia bibliografía en conceptos potencialmente relevantes para la ecología política de la conservación.

Palabras clave: conservación, gubernamentalidad, preferencia, naturaleza, mercantilización de la naturaleza, territorialidad 